\title{
СОВРЕМЕННЫЕ ПРОБЛЕМЫ ЗЕМЛЕУСТРОЙСТВА И КАДАСТРА ТУРЦИИ
}

\section{Мария Викторовна Бокарева}

Московский государственный университет геодезии и картографии, 105064, Россия, г. Москва, Гороховский переулок, 4, обучающийся, тел. (965)716-20-25, e-mail: bokareva2602@gmail.ru

\section{Александр Павлович Сизов}

Московский государственный университет геодезии и картографии, 105064, Россия, г. Москва, Гороховский переулок, 4, доктор технических наук, зав. кафедрой кадастра и основ земельного права, тел. (906)716-27-10, e-mail: ap_sizov@mail.ru

Публикация представляет собой обзор современного состояния земельных ресурсов, системы кадастра и землеустройства в Турции. Рассмотрена история системы, ее структура и функции регистрации, особенности регистрации прав иностранцев, изучен основной генеральный директорат земельного регистра и кадастра (GDLRC). В заключении отмечены рекомендации по созданию национальной программы и улучшению функций программы “Подземный кадастр".

Ключевые слова: кадастр, землеустройство, устойчивое развитие, система, программа, территория, инфраструктура

\section{MODERN PROBLEMS OF LAND MANAGEMENT AND CADASTRE IN TURKEY}

\section{Maria $V$. Bokareva}

Moscow State University of Geodesy and Cartography, 4, Gorokhovsky Lane, Moscow, 105064, Russia, Student, phone: (965)716-20-25, e-mail: bokareva2602@gmail.ru

\section{Alexander P. Sizov}

Moscow State University of Geodesy and Cartography, 4, Gorokhovsky Lane, Moscow, 105064, Russia, D. Sc., Head of the Department of Cadastre and Foundations of Land Law, phone: 7(906)716-27-10, e-mail: ap_sizov@mail.ru

The publication is an overview of the current state of land resources, cadastre and land management systems in Turkey. The history of the system, its structure and functions of registration, features of registration of foreigners ' rights, and the main Directorate General of the land register and cadastre (GDLRC) are considered. In conclusion, recommendations for creating a national program and improving the functions of the "Underground cadastre" program are noted.

Keywords: cadastre, land management, sustainable development, system, program, territory, infrastructure

\section{Введение}

Цель работы - анализ проблем землеустройства и кадастра в Турции.

Основные задачи:

1. Составить общую характеристику данного государства.

2. Рассмотреть и охарактеризовать земельные ресурсы государства.

3. Изучить правовые основы использования и управления земельными ресурсами. 
4. Выявить современные проблемы землеустройства и кадастра в Турции.

Объектом исследования является территория государства - Турции. Предметом исследования является информация о землеустройстве и кадастре.

Методами исследования являются анализ и синтез информации.

\section{Общая характеристика объекта исследования}

Официальное название - Турецкая Республика. Расположена на стыке двух континентов. Общая площадь 783577 кв. км, 759752 кв. км (97\%) в Азии и 23825 кв. км (3\%) в Европе. Численность населения - 84 млн. чел.

Форма правления - президентская республика, состоит из 81 провинции. Законодательная функция в Турции принадлежит однопалатному парламенту Великому национальному собранию Турции (ВНСТ), включающему в свой состав 550 депутатов. Исполнительная власть осуществляется президентом и Советом министров. Глава государства - президент республики.

Турция - горная страна. Средняя высота её территории над уровнем моря составляет 1132 м. С севера территория страны опоясана Северо-Анатолийскими горами, наиболее высокая точка которых находится в восточной части - гора Качкар (3932 м). С юга территорию Турции опоясывает горная система Тавр, не являющаяся однородной. Внутренняя часть территории страны постепенно повышается в направлении с запада на восток: анатолийское плоскогорье переходит в более возвышенную часть Турции - Восточно-Анатолийское нагорье, где и находится самая высокая горная вершина Турции - Большой Арарат (5137 м). Низменных равнин на территории Турции мало (в основном они в устьях рек).

На территории Турции находится большое количество рек и озёр, хотя её насыщенность водными ресурсами имеет неравномерный характер. Реки Турции имеют преимущественно горный характер, не судоходны, но обладают значительными запасами гидроэнергии.

Флора Турции богата и разнообразна, она включает 6500 видов растений. В пределах страны выделяются две основные растительные зоны - приморская и внутренняя. Первая представлена растительностью субтропиков. Внутренняя зона сформировалась в местах отделенных горами от морских побережий центральных районах Турции. Она представлена степными и полупустынными видами. На склонах гор, обращенных к морям, произрастают различные по составу леса. Турция находится в зоне субтропического климата, однако особенности рельефа предопределяют разнообразие климатических условий страны, для внутренних районов которой характерен континентальный климат. Осадки распределены по территории Турции неравномерно, наибольшая их часть приходится на восточную часть черноморского побережья. В южной части анатолийского плоскогорья - режим осадков, характерный для полупустынных районов.

\section{Характеристика земельных ресурсов}

В Турции преобладают горные почвы, которые маломощны и малоплодородны. Среди равнинных почв встречаются бурозёмы, краснозёмы, серозёмы, каштановые почвы и солончаки. Чернозёмов в Турции мало. В основном они 
имеют аллювиальное происхождение, располагаясь на прибрежных равнинах, образованных устьями рек, или в их долинах. Около 80\% поверхности Турции занимают малоплодородные горные почвы. Для получения гарантированных урожаев необходимо проводить мелиоративные работы. Сельскохозяйственная земля составляет $49,8 \%$ от земельной площади, $15,4 \%$ - лесная площадь.

Наибольшую площадь с точки зрения землепользования в стране составляют луговые и пастбищные угодья. Площадь земель, непригодных для сельского хозяйства, составляет более $14 \%$. Около $70 \%$ территории Турции находится под угрозой сильной эрозии. Наиболее важными причинами эрозии являются деятельность населения, практика паров в сельскохозяйственной деятельности, а также рельеф местности неровный и наклонный. На большей части сельскохозяйственных угодий в стране выращивают сухое земледелие (зернохранилище). Зерновое земледелие широко распространено в плато и равнинных районах, особенно в континентальных климатических зонах. Здесь распространены степные почвы коричневого и каштанового цвета. Бобовые произрастают на 8\% полевых земель. Промышленные культуры составляют 7\% от площади сельскохозяйственных угодий. На этих землях выращиваются сахарная свекла, хлопок, табак, чай, мак и лен. Чайное земледелие наблюдается на восточном побережье Черного моря, где обычно наблюдаются влажные и вымытые почвы.

Почва используется в качестве сырья в различных отраслях промышленности, включая цементную. Сырьем для кирпичной, черепичной, керамической, фарфоровой и стекольной промышленности является глинистая почва.

\section{Кадастр и землепользование в Турции}

Площадь 780000 кв. км, из которых 40000 кв. км - застроенные территории. Кадастром покрыто $100 \%$ земель. Земельный кадастр в Турции возник во времена Оттоманской империи еще в 15 веке. Первая организация по ведению земельного кадастра была создана после перехода Турции к частной собственности на землю 21 мая 1847 года. Она получила название «Офис государственного регистра». Регистр служил целям налогообложения и определения собственности, но при этом кадастровые измерения границ долгое время не проводились. Первый Закон о кадастре появился в 1913 году под названием «Закон об определении и управлении активами и недвижимой собственностью». Этот закон, кроме всего прочего, стал регулировать кадастровые работы. В это же время была создана специальная «кадастровая школа».

После образования Турецкой Республики, в 1924 году появился Генеральный директорат земельного регистра и кадастра (GDLRC). В 1925 году специальным Законом к нему была присоединена кадастровая служба. Сегодняшняя структура и цели этого директората были определены уже в 1939 году. Генеральный Директорат GDLRC в разные периоды времени подчинялся разным государственным органам: Министерству финансов (1936-1939), Министерству юстиции (1939-1951), непосредственно Премьер Министру (1951-2002), Министерству государственных работ и учреждений (2002-2011). С 2011 года нахо- 
дится в структуре Министерства окружающей среды и территориального планирования.

В декабре 2010 года вошел в силу Закон № 6083 «Об организации и обязанностях Генерального директората по земельному регистру и кадастру». Закон следующим образом определил функции GDLRC:

a) ведение земельного регистра, архива документов путем регистрации недвижимого имущества и транзакций прав на него;

б) выполнение в стране всех видов кадастровых работ;

в) предоставление услуг геодезической инфраструктуры, аэрофотограмметрии, производство фотограмметрических работ и карт масштабом 1:5000 и крупнее;

г) создание национальной инфраструктуры пространственных данных, центра мониторинга картографической продукции, решение задач различного назначения с использованием ГИС;

д) оформление транзакций прав с участием иностранных граждан и юридических лиц, защита прав и интересов субъектов гражданского права Турции за рубежом, проведение трансграничных переговоров по недвижимости;

е) планирование и исполнение совместных проектов с зарубежными организациями;

ж) лицензирование кадастровых инженеров;

3) регулирование деятельности риэлторов, их лицензирование, определение принципов их работы, мониторинг их деятельности.

В структуру директората GDLRC входит центральный и 24-е региональных офиса. Последние включают 81 кадастровое подразделение и 970 подразделений земельного регистра. В структуру Центрального офиса GDLRC входят 13 департаментов: по главным видам деятельности: департамент земельного регистра, кадастровый, картографический департаменты, департамент иностранных дел и департамент управления архивом; по аудиту и консалтингу: совет инспекторов, департамент юридических консультаций, департамент стратегического развития, департамент внутреннего аудита, вспомогательные службы: департамент человеческих ресурсов (отдел кадров), вспомогательных сервисов, департамент информационной техники, финансовый департамент.

В течение последнего десятилетия в Турции получила широкое распространение продажа жилой недвижимости иностранцам для отдыха, а также инвесторам со всего мира. Впервые такие продажи стали возможны после появления закона о земельном регистре 1934 года.

Лица иностранной национальности могут купить любой вид имущества: земельный участок, жилой дом, территорию для бизнеса, землю сельскохозяйственного, но с определенными юридическими ограничениями. Например, иностранцы, которые покупают свободные (незастроенные) земельные участки обязаны представить девелоперский проект в соответствующее Министерство на согласование в течение 2 лет. 
Согласно Турецкому законодательству передача прав собственности иностранцу возможна по договору, который подписывается непосредственно в офисах GDLRC. К нотариусам для таких сделок можно не обращаться. Для иностранца не требуется разрешения на жительство для приобретения имущества. Имеются и ограничения для иностранцев, приобретающих недвижимость: лица иностранного гражданства могут купить земельные участки общей площадью максимум 30 га; иностранцы не могут покупать или арендовать недвижимость в зонах, обозначенных в целях национальной безопасности; иностранцы в общей сложности не могут скупить более 10 процентов территорий населенного пункта; права иностранцев подлежат прекращению, если соответствующие Министерства или администрации установили, что имущество используется не по назначению; если иностранное лицо не представило в соответствующее Министерство в заданное время девелоперский проект развития земельного участка.

\section{Основная проблема системы землеустройства и кадастра Турции}

В настоящий момент в Турции отсутствует база пространственных данных, которая помогала бы грамотно управлять государством.

Учёт пространственных объектов, начиная от поворотных точек земельного участка и заканчивая деревцом в парке, обеспечивает легкую функциональность всего хозяйства в целом. Ведущая роль кадастра в создании национальной инфраструктуры геопространственных данных определяется тем, что в процессе его составления и формирования уточняются и дополняются базы пространственной информации, то есть данные о местности, топографии.

Кадастровые данные содержат информацию о собственности и правовом статусе земельных угодий, а это имеет большое значение для территориального планирования. Банк геопространственных данных, или инфраструктура геопространственных данных, - это путь к решению многих проблем в управлении государством. Это система общегосударственного географического архива, где содержатся все топографические, картографические данные. Система географического архива позволяет вести учет национальных богатств, усилить их охрану, уменьшить расходы по содержанию исторических памятников, национальных парков, на мониторинг использования природных ресурсов, так как постоянно обновляемая информация обеспечивает своевременное и правильное распределение затрат средств и труда в этих направлениях. Это достоверный учёт для земельного кадастра. Наличие такой информации определяет правильное составление градостроительных планов и оценку недвижимости. А это фундамент системы налогового регулирования в государстве, справедливое начисление налогов на имущество.

\section{Заключение}

Турция относится к развивающимся странам и должна особое внимание уделять проблемам в кадастре и землеустройстве. Страна нуждается в правильном подходе к устойчивому развитию территорий. Создание национальной 
программы поможет в борьбе с опустыниванием и водной эрозией. Необходимо внести в программу разработку критериев и показателей устойчивого управления землями.

Рассмотрение защиты природных ресурсов и окружающей среды в региональном и городском планировании принято в законе № 5403 “О защите земель и землепользовании" и в дополнение к этому нужно рассмотреть концепцию устойчивого управления земельными ресурсами.

Также в Турции идет активное развитие по разработке программы "Подземный кадастр". Эта программа выполняет одну из главных функций градостроительного управления освоением подземного пространства - кадастровый учет подземных зданий и сооружений. Основные задачи будут выполняться с помощью системы, которая будет создана путем добавления третьего измерения в двумерный кадастр.

\section{БИБЛИОГРАФИЧЕСКИЙ СПИСОК}

1. Географический сайт. Турция. https://geo-1.ru/turtsiya-informatsiya-o-strane.

2. Лекция по истории земельного кадастра Турции. https://pandia.ru/text/78/256/86518.php.

3. Портал о международной защите активов и диверсификации активов. https://internationalwealth.info/fast-legal-second-citizenship-and-passport/obtain-turkish-economiccitizenship-on-real-estate-investments/.

4. Закон о приобретении недвижимости в Турции иностранцами https://pravoturkey.ru/law/zakon-o-priobretenii-nedvizhimosti-v-turtsii-inostrantsami/.

(C) М. В. Бокарева, А. П. Сизов, 2021 